University of Nebraska - Lincoln

DigitalCommons@University of Nebraska - Lincoln

Agronomy \& Horticulture -- Faculty Publications

Agronomy and Horticulture Department

February 2005

\title{
Overseeding Buffalograss Turf with Fine-Leaved Fescues
}

\author{
Songul Severmutlu \\ University of Nebraska-Lincoln, ssevermutlu3@unl.edu \\ Terrance P. Riordan \\ University of Nebraska-Lincoln, triordan1@unl.edu \\ Robert C. Shearman \\ University of Nebraska-Lincoln, rshearman1@unl.edu \\ Roch E. Gaussoin \\ University of Nebraska-Lincoln, rgaussoin1@unl.edu \\ Lowell E. Moser \\ University of Nebraska-Lincoln, Imoser1@unl.edu
}

Follow this and additional works at: https://digitalcommons.unl.edu/agronomyfacpub

Part of the Plant Sciences Commons

Severmutlu, Songul; Riordan, Terrance P.; Shearman, Robert C.; Gaussoin, Roch E.; and Moser, Lowell E., "Overseeding Buffalograss Turf with Fine-Leaved Fescues" (2005). Agronomy \& Horticulture -- Faculty Publications. 47.

https://digitalcommons.unl.edu/agronomyfacpub/47

This Article is brought to you for free and open access by the Agronomy and Horticulture Department at DigitalCommons@University of Nebraska - Lincoln. It has been accepted for inclusion in Agronomy \& Horticulture -Faculty Publications by an authorized administrator of DigitalCommons@University of Nebraska - Lincoln. 


\title{
Overseeding Buffalograss Turf with Fine-Leaved Fescues
}

\author{
S. Severmutlu, T. P. Riordan, R. C. Shearman,* R. E. Gaussoin, and L. E. Moser
}

\begin{abstract}
Buffalograss [Buchloe dactyloides (Nutt.) Engelm.] use as a turf in the northern USA is limited to a certain extent by its extended winter dormancy. A mixture of buffalograss with cool-season turfgrasses might extend the turf's green appearance and enhance quality. Research was conducted to determine the effects of overseeding fineleaved fescue (Festuca spp.) in buffalograss turf on turfgrass color and quality and the effects of species, seeding rate and date, and core cultivation on fine-leaved fescue establishment in buffalograss turf. Hard fescue ( $F$. longifolia Thuill.), blue fescue ( $F$. ovina $L$. var. glauca Lam.), and Chewings fescue ( $F$. rubra L. ssp. commutata Gaud.); seeding rates $\left(10,20\right.$, and $\left.30 \mathrm{~g} \mathrm{~m}^{-2}\right)$; seeding dates (fall, spring, or split fall-spring); and core cultivation (single or double pass) were evaluated for species composition, turfgrass quality, color, and green cover at the John Seaton Anderson Turfgrass Research Facility located near Mead, NE. Buffalograss turf overseeded with blue fescue in fall had the highest turfgrass quality, color, and green cover ratings. Fall overseeding resulted in the highest shoot density values. Spring overseedings were below acceptable levels. Botanical composition of the mixtures overseeded in fall reached 75 to $80 \%$ fescue and 20 to $25 \%$ buffalograss after 2 yr. Seeding rate effect was linear with each increment between $10 \mathrm{~g} \mathrm{~m}^{-2}$ and $30 \mathrm{~g} \mathrm{~m}^{-2}$ increasing fine-leaved fescue shoot density, turfgrass quality, color, and green cover. Blue fescuebuffalograss mixtures overseeded in the fall exhibited $80 \%$ green cover when buffalograss was dormant. Turfgrass green cover in the mixture was extended by 2 months when compared to buffalograss monostands growing in areas adjacent to the study. The results of this study support the use of fine-leaved fescue and buffalograss mixtures to extend turfgrass green appearance and enhance quality.
\end{abstract}

$\mathrm{B}$ UFFALOGRASS is a low-maintenance, stoloniferous, perennial warm-season species native to the North American Great Plains (Wenger, 1943). Buffalograss has excellent drought resistance and requires minimal maintenance (Wenger, 1940; Pozarnsky, 1983). Turf-type buffalograsses have been developed for use on lawns, golf courses, institutional grounds, parks, and roadsides (Falkenberg-Borland and Butler, 1982; Pozarnsky, 1983). Buffalograss becomes dormant early in the fall and remains dormant until late spring throughout the Great Plains region. The annual dormancy period is a limiting factor to the acceptance of buffalograss as a turfgrass.

Temporary overseeding of warm-season turfs with cool-season grasses is common in the southern portions of the USA (Foy, 1998; Longer, 1998). Permanent cooland warm-season turfgrass mixtures are not common due to difficulties in maintaining the desired botanical composition (Davis, 1958; Beard, 1973; Johnson, 2003). However, successful cool- and warm-season grass mix-

Dep. of Agronomy and Horticulture, Univ. of Nebraska-Lincoln, Lincoln, NE 68583-0724. Journal Series No. 14491; Agric. Res. Div., University of Nebraska-Lincoln. Received 20 Feb. 2004. Forage \& Grazing Lands.*Corresponding author (rshearman1@unl.edu).

Published in Crop Sci. 45:704-711 (2005)

(c) Crop Science Society of America

677 S. Segoe Rd., Madison, WI 53711 USA tures exist in forage, pasture, and turfgrass areas (Stoutemyer, 1953; Youngner, 1958; Wilkinson et al., 1968; Petersen and Moser, 1985; Pitman, 1999).

Fine-leaved fescues including hard fescue (HF), blue fescue (BF), sheep fescue ( $F$. ovina L.), Chewings fescue $(\mathrm{CF})$, and creeping red fescue (F. rubra L. ssp. rubra) are adapted to low-maintenance use (Roberts, 1990; Watschke, 1990) and are drought resistant but do not tolerate high-temperature stress (Hanson et al., 1969). These characteristics could complement buffalograss in turfgrass mixtures.

This study was conducted to determine the effects of overseeding fine-leaved fescue in buffalograss turf on turfgrass color and quality and the effects of species, seeding rate and date, and core cultivation on fine-leaved fescue establishment in buffalograss turf.

\section{MATERIALS AND METHODS}

Seeding date and seeding rate studies were conducted at the John Seaton Anderson Turfgrass Research Facility located near Mead, NE. The soil was a Tomek silty-clay loam (fine, smectitic, mesic Pachic Argiudolls). The experimental design was a randomized complete block with treatments arranged in a 3 (species) $\times 3$ (seeding rate or seeding date $) \times 2$ (core cultivation) factorial. Treatments were replicated three times and treatment plot size was 1.5 by $2.4 \mathrm{~m}\left(3.6 \mathrm{~m}^{2}\right)$.

Mature stands of 'Prestige' and 'NE 86-120' buffalograss used in the seeding date and seeding rate studies, respectively, were mowed at $25 \mathrm{~mm}$ and clipping debris was removed before overseeding. Cultivation treatments were coring (CC) once (single-pass CC) or twice (double-pass CC). Fine-leaved fescues included 'SR 3100' HF, 'SR 3200' BF, and 'SR 5100' $\mathrm{CF}$. The seeding date study consisted of fall, spring, or split fall-spring treatments. Treatments were applied on 5 Sept. 2001 (fall) and 15 May 2002 (spring), and fall-spring treatments were applied on both dates. Seed was sown at $20 \mathrm{~g} \mathrm{~m}^{-2}$ for fall and spring treatments and $10 \mathrm{~g} \mathrm{~m}^{-2}$ for the fall-spring treatment. The study was repeated on 3 Sept. 2001 and 20 May 2002. The seeding rate treatments were 10,20 , and $30 \mathrm{~g}$ $\mathrm{m}^{-2}$ and the study was seeded initially on 5 Sept 2001 and repeated on 20 May 2002. Different seedlots were used in 2001 and 2002 overseedings.

Turfs were fertilized at $5 \mathrm{~g} \mathrm{~N} \mathrm{~m}^{-2}(16 \mathrm{~N}-11 \mathrm{P}-10 \mathrm{~K})$, immediately after overseeding, and were irrigated three times daily at $6 \mathrm{~mm}$ to maintain a moist soil surface for $3 \mathrm{wk}$ after seeding. Subsequently, turfs received a minimum of $12 \mathrm{~mm}$ water weekly during the growing season. Turfs were mowed weekly at $50 \mathrm{~mm}$ with clippings returned. After establishment, turf received $10 \mathrm{~g} \mathrm{~N} \mathrm{~m}^{-2}$ per season with applications made as $2.5 \mathrm{~g} \mathrm{~N} \mathrm{~m}^{-2}$ in May, $5 \mathrm{~g} \mathrm{~N} \mathrm{~m}^{-2}$ in July, and $2.5 \mathrm{~g} \mathrm{~N} \mathrm{~m}^{-2}$ in October, using $38 \mathrm{~N}-0 \mathrm{P}-0 \mathrm{~K}$. Soil samples were taken in April before fertilizer applications and soil tests indicated P $(72 \mathrm{mg}$ $\left.\mathrm{kg}^{-1}\right)$ and $\mathrm{K}\left(375 \mathrm{mg} \mathrm{kg}^{-1}\right)$ levels were sufficient.

Shoot density and stand composition were determined in May, July, and September. Counts were made on one-half of a 100-mm-diameter plug and were reported as shoot number

Abbreviations: BF, blue fescue; CC, core cultivation; CF, Chewings fescue; HF, hard fescue. 
Table 1. Analysis of variance (ANOVA) for turfgrass quality, color, green cover and fine fescue and buffalograss shoot density as influenced by overseeded fine fescue species, seeding date, and core cultivation.

\begin{tabular}{|c|c|c|c|c|c|c|}
\hline \multirow[b]{2}{*}{ Source of variation } & \multirow[b]{2}{*}{ df } & \multirow[b]{2}{*}{ Quality } & \multirow[b]{2}{*}{ Color } & \multirow[b]{2}{*}{ Green cover } & \multicolumn{2}{|c|}{ Shoot density $\dagger$} \\
\hline & & & & & Fine fescue & Buffalograss \\
\hline Year $(\mathbf{Y})$ & 1 & $(3 / 7)^{*}+$ & $(5 / 7)^{*}$ & $(4 / 7) *$ & $(3 / 3) *$ & $(2 / 3)^{*}$ \\
\hline Overseeded species (S) & 2 & $(7 / 7)^{*}$ & $(7 / 7)^{*}$ & $(5 / 7)^{*}$ & $(3 / 3) *$ & $(2 / 3) *$ \\
\hline Core cultivation (CC) & 1 & ns§ & ns & (1/7)* & ns & $(1 / 3) *$ \\
\hline Seeding date (SD) & 2 & $(7 / 7)^{*}$ & $(6 / 7)^{*}$ & $(6 / 7)^{*}$ & $(3 / 3) *$ & $(3 / 3) *$ \\
\hline $\mathbf{S} \times \mathbf{C C}$ & 2 & ns & ns & ns & ns & ns \\
\hline $\mathbf{S} \times \mathbf{S D}$ & 4 & $(7 / 7)^{*}$ & $(7 / 7)^{*}$ & $(6 / 7)^{*}$ & $(3 / 3) *$ & $(3 / 3) *$ \\
\hline $\mathbf{C C} \times \mathbf{S D}$ & 2 & ns & ns & ns & ns & ns \\
\hline $\mathbf{S} \times \mathbf{C C} \times \mathbf{S D}$ & 4 & ns & ns & ns & ns & ns \\
\hline $\mathbf{Y} \times \mathbf{S}$ & 2 & $(5 / 7)^{*}$ & $(5 / 7)^{*}$ & $(5 / 7)^{*}$ & $(\mathbf{3} / 3) *$ & $(3 / 3)^{*}$ \\
\hline $\mathbf{Y} \times \mathbf{C C}$ & $\mathbf{1}$ & ns & $(1 / 7)^{*}$ & $(1 / 7)^{*}$ & ns & ns \\
\hline $\mathbf{Y} \times \mathbf{S D}$ & 2 & $(6 / 7)^{*}$ & $(6 / 7)^{*}$ & $(5 / 7)^{*}$ & $(3 / 3) *$ & $(1 / 3) *$ \\
\hline $\mathbf{Y} \times \mathbf{S} \times \mathbf{C C}$ & 2 & ns & ns & ns & ns & ns \\
\hline $\mathbf{Y} \times \mathbf{S} \times \mathbf{S D}$ & 4 & $(1 / 7)^{*}$ & $(2 / 7) *$ & $(1 / 7)^{*}$ & ns & $(2 / 3) *$ \\
\hline $\mathbf{Y} \times \mathbf{C C} \times \mathbf{S D}$ & 2 & ns & ns & ns & ns & ns \\
\hline $\mathbf{Y} \times \mathbf{S} \times \mathbf{C C} \times \mathbf{S D}$ & 4 & ns & ns & ns & ns & ns \\
\hline Error & 68 & & & & & \\
\hline
\end{tabular}

* Significant at the 0.05 probability level.

$\dagger$ The number of fine fescue or buffalograss shoots in $4000 \mathrm{~mm}^{-2}$.

$\$$ Number in parentheses indicates number of evaluations when treatment differences were significant at $P \leq 0.05$ over total number of evaluations.

$\S \mathrm{ns}=$ nonsignificant at the 0.05 probability level.

per square meter. Stand composition was expressed as a percentage of each species based on the shoot density counts. A 1.5 by $2.4 \mathrm{~m}$ frame containing 40 grids of $0.09 \mathrm{~m}^{2}$ was constructed to fit the treatment plot. The frame was laid on the turf and four plugs were randomly taken from each treatment plot. Plugs were returned to their original location after counting and subsequent samples were not taken from those locations. Turfgrass quality was rated monthly from April to No- vember using a visual rating scale of 1 to 9 , with $1=$ poorest, $6=$ acceptable, and $9=$ best. Turfgrass color was rated monthly, using a visual rating scale of 1 to 9 , with $1=$ straw brown, $6=$ light green, and $9=$ dark green. Turfgrass green cover was rated monthly using a visual rating scale of 0 to $100 \%$, with $0 \%=$ no green vegetation and $100 \%=$ green vegetation over the entire area.

Analysis of variance was performed with PROC GLM (SAS

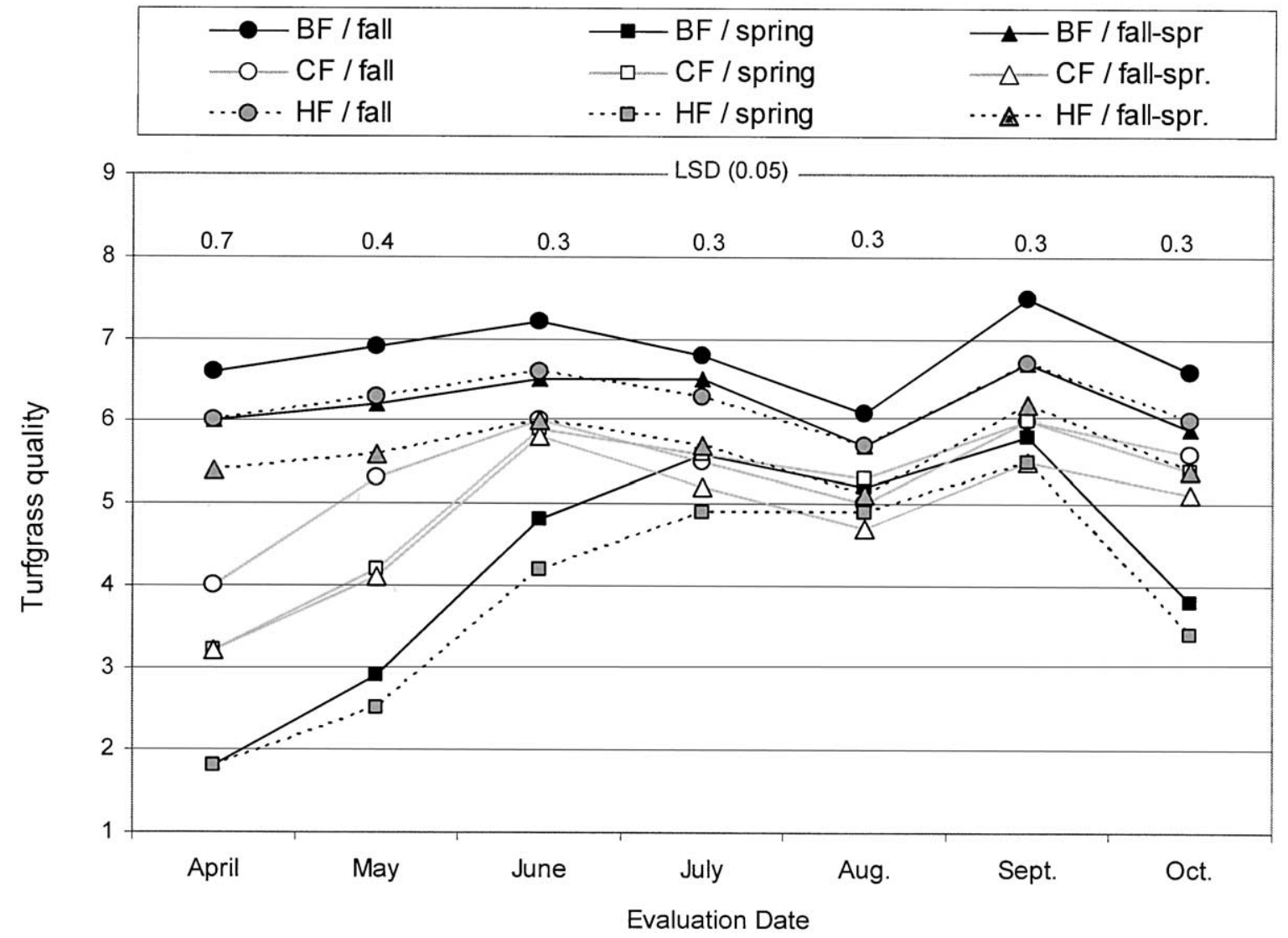

Fig. 1. Mean turfgrass quality for fall, spring, and fall-spring overseeded blue fescue (BF), hard fescue (HF), and Chewings fescue (CF) treatments averaged over 2002 and 2003 . Turfgrass quality ratings were based on a 1-9 visual rating scale, with $1=$ poorest, $6=$ acceptable, $9=$ best. LSD values are for comparing within or between species or seeding dates. 


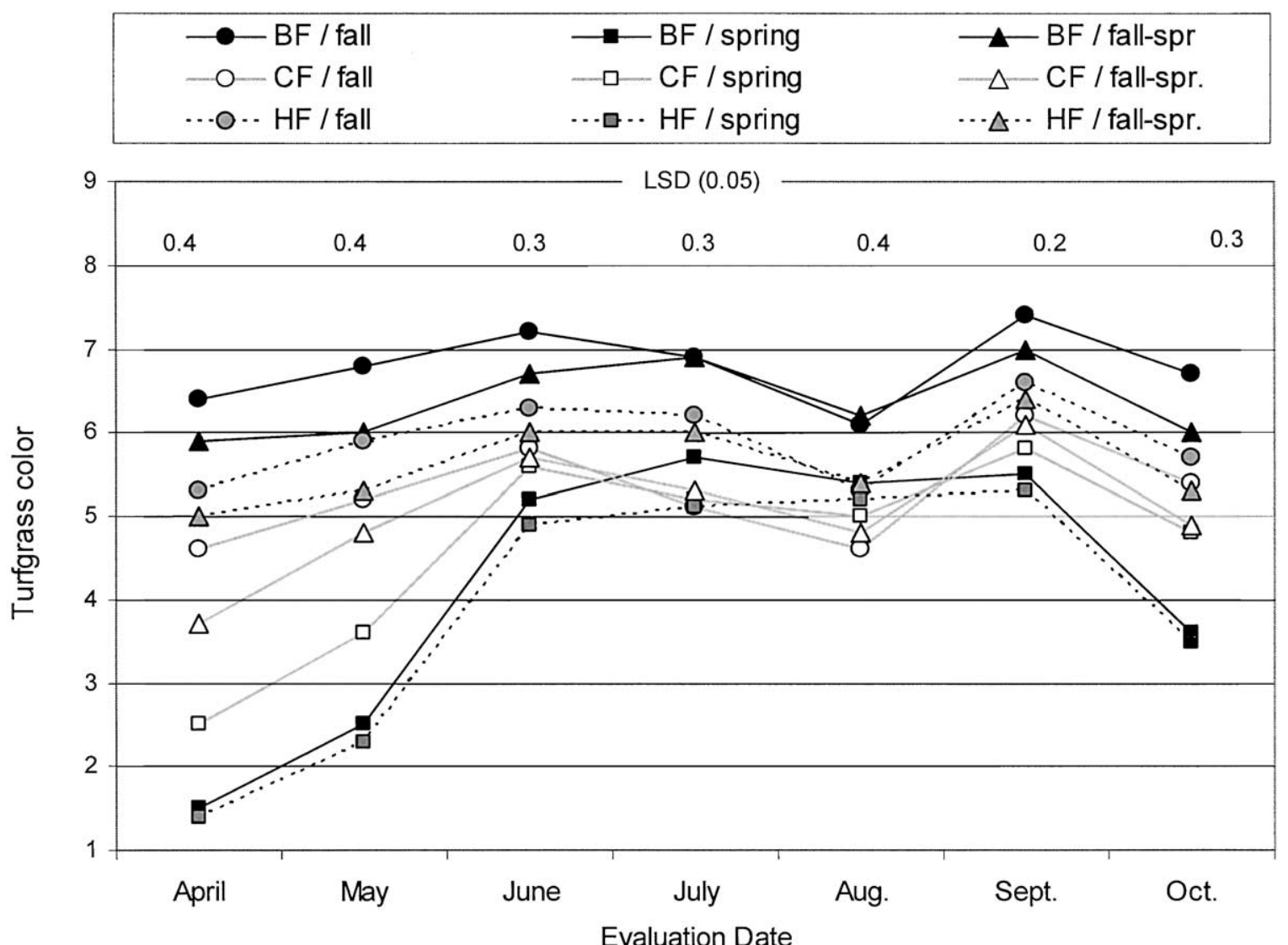

Fig. 2. Mean turfgrass color ratings for fall, spring, and fall-spring overseeded blue fescue (BF), hard fescue (HF), and Chewings fescue (CF) treatments averaged over 2002 and 2003 . Turfgrass color was based on a 1-9 visual rating scale, with $1=$ straw brown, $6=$ light green, $9=$ dark green. LSD values are for comparing within or between species or seeding dates.

Institute, 1999) and means were separated using Fisher's protected least significant difference $(P<0.05)$. A Hartley's $\mathrm{F}$ max test (Hartley, 1950) was performed to determine homogeneity of variance between the first and second trials in each study.

\section{RESULTS AND DISCUSSION}

\section{Seeding Date Study}

Data from the first and second trials were combined because the F max test (Hartley, 1950) resulted in accepting the hypothesis of homogeneity of variance between the two trials. There were significant interactions for turfgrass color, green cover, and density between years and species or seeding dates on some evaluation dates (Table 1). However, trends were similar for both years and data were not reported separately. There were significant seeding date $\times$ species interactions for turfgrass quality, color, and green cover and for species shoot density during this study (Table 1).

Buffalograss overseeded with fine-leaved fescues in the fall produced the best turfgrass quality, darkest green color, and most green cover when buffalograss was dormant in late fall and spring (Fig. 1, 2, 3). Fall overseeding resulted in the highest shoot density values for the fineleaved fescue species and spring seeding resulted in low shoot density values (Table 2). Fine fescue comprised $80 \%$ of the tillers in the fall and $75 \%$ in the fall-spring seeding treatments, while the spring treatment was around $26 \%$ for $\mathrm{BF}$ and $\mathrm{HF}$, and $58 \%$ for $\mathrm{CF}$. These results support fall overseeding of fine-leaved fescues as being superior to spring.

Among the fall overseedings, $\mathrm{HF}$ and $\mathrm{CF}$ had higher shoot density values than $\mathrm{BF}$ (Table 2). Fine fescue composition was highest in May and gradually declined until September, when it rebounded with the onset of cool temperatures. The decline of fine-leaved fescues in the summer was likely due to unfavorable growing conditions and increased interference from buffalograss.

Fall overseeded BF had the highest ratings for turfgrass quality and color throughout the study (Fig. 1,2). Several factors may have contributed to this result, such as more consistent appearance in color, texture, and cover. The blue-green color of $\mathrm{BF}$ blended well with the buffalograss cultivar in this study. The BF also contributed to better turfgrass color in the mixture during the summer, when HF and CF exhibited more summer stress symptoms than BF. The BF treatment maintained a very dense and attractive weed-free turf. In Utah, Johnson (2003) reported similar results with BF and buffalograss mixtures providing the best turfgrass quality and uniformity when compared to $\mathrm{CF}$ and creeping red fescue buffalograss mixtures. In this study, CF overseeding treatments gave unacceptable quality ratings when buffalograss was dormant.

Fall and spring turfgrass quality and color ratings were better than summer (Fig. 1, 2). Decreases in turfgrass color and green cover were caused by high temperature 


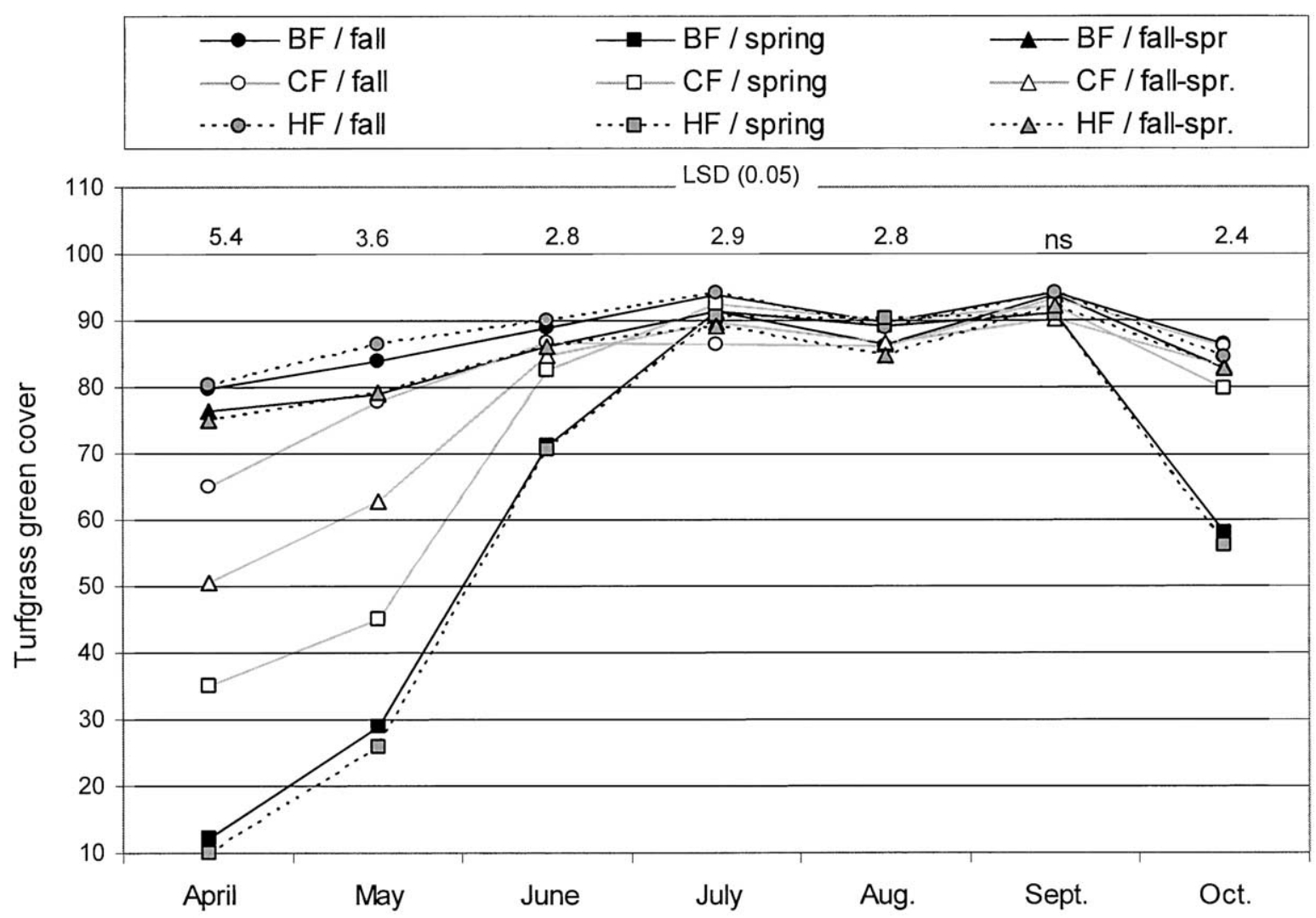

Evaluation Date

Fig. 3. Mean turfgrass green cover for fall, fall-spring, and spring overseeded blue fescue (BF), hard fescue (HF), and Chewings fescue (CF) treatments averaged over 2002 and 2003. Turfgrass green cover was rated using a visual estimate of $0-100 \%$ of existing turfgrass. LSD values are for comparing within or between species or seeding dates.

stress and brown patch (caused by Rhizoctania solani Kühn). Fall overseeded BF maintained acceptable and higher quality ratings than $\mathrm{HF}$ and $\mathrm{CF}$, and had less summer stress and disease pressure than $\mathrm{HF}$ and $\mathrm{CF}$. In Maryland, Dernoeden et al. (1998) reported that monostands of BF and HF maintained better turfgrass quality in summer than CF or creeping red fescue. Baker and Jung (1968) and Wehner and Watschke (1981) reported reduced turfgrass quality and green cover for cool-season turfgrasses in response to high temperature stress. The combined performance of BF and buffalograss appeared to maintain the acceptable quality rat- ings during the summer stress period. Above average soil and air temperatures, and below the 10-yr average precipitation were observed at the research site during June and July. Turfgrass quality and color ratings improved for all treatments once high temperatures subsided and precipitation returned to normal. These results indicate that the buffalograss may have been stressed during the higher than normal temperatures and reduced precipitation experienced during this study.

Spring overseeding resulted in a poor establishment, which gave rise to a patch-like turf appearance and weed problems. Spring overseeded HF and BF had the lowest

Table 2. Mean shoot density for fine fescue and buffalograss and percentage of fine fescues in mixtures as influenced by species and seeding dates.

\begin{tabular}{|c|c|c|c|c|c|c|c|c|}
\hline \multirow[b]{3}{*}{ Overseeded species } & \multirow[b]{3}{*}{ Seeding date } & \multicolumn{6}{|c|}{ Shoot density } & \multirow{3}{*}{$\begin{array}{l}\text { Fine fescue } \\
\text { composition } \\
\text { of mixture } \dagger\end{array}$} \\
\hline & & \multicolumn{2}{|c|}{ May } & \multicolumn{2}{|c|}{ July } & \multicolumn{2}{|c|}{ September } & \\
\hline & & fine fescue & buffalograss & fine fescue & buffalograss & fine fescue & buffalograss & \\
\hline & & & & - No. & $0^{4} \mathrm{~m}^{-2}$ & & & $\%$ \\
\hline \multirow[t]{3}{*}{ Blue fescue } & fall & 132 & 14 & 77 & 33 & 87 & 33 & 79 \\
\hline & fall-spring & 115 & 16 & 62 & 39 & 74 & 42 & 72 \\
\hline & spring & 28 & 51 & 17 & 77 & 21 & 78 & 24 \\
\hline \multirow[t]{3}{*}{ Chewings fescue } & fall & 116 & 20 & 90 & 29 & 111 & 30 & 80 \\
\hline & fall-spring & 100 & 23 & 79 & 34 & 95 & 31 & 76 \\
\hline & spring & 71 & 46 & 68 & 51 & 71 & 53 & 58 \\
\hline \multirow[t]{3}{*}{ Hard fescue } & fall & 160 & 13 & 86 & 31 & 106 & 35 & 82 \\
\hline & fall-spring & 147 & 15 & 72 & 35 & 89 & 37 & 78 \\
\hline & spring & 31 & 52 & 17 & 76 & 32 & 82 & 28 \\
\hline LSD $(0.05) \div$ & & 8.0 & 4.7 & 6.6 & 4.3 & 6.1 & 4.6 & \\
\hline
\end{tabular}

$\dagger$ Fine fescue composition of the mixture averaged over growing season.

+ LSD for significant seeding date $\times$ species interactions. 
Table 3. Analysis of variance (ANOVA) for turfgrass quality, color, green cover, and fine fescue and buffalograss shoot density as influenced by overseeded fine fescue species, seeding rate, and core cultivation.

\begin{tabular}{|c|c|c|c|c|c|c|}
\hline \multirow[b]{2}{*}{ Source of variation } & \multirow[b]{2}{*}{ df } & \multirow[b]{2}{*}{ Quality } & \multirow[b]{2}{*}{ Color } & \multirow[b]{2}{*}{ Green cover } & \multicolumn{2}{|c|}{ Shoot density $\dagger$} \\
\hline & & & & & Fine fescue & Buffalograss \\
\hline Year (Y) & 1 & $(4 / 7) * \div$ & $(2 / 7)^{*}$ & $(4 / 7)^{*}$ & $(2 / 3)^{*}$ & $(1 / 3)^{*}$ \\
\hline Overseeded species (S) & 2 & $(7 / 7)^{*}$ & $(7 / 7)^{*}$ & $(7 / 7)^{*}$ & $(3 / 3)^{*}$ & $(3 / 3)^{*}$ \\
\hline Core cultivation (CC) & 1 & $(1 / 7)^{*}$ & $(2 / 7)^{*}$ & $(1 / 7)^{*}$ & $(3 / 3)^{*}$ & $(3 / 3)^{*}$ \\
\hline Seeding rate (SR) & 2 & $(5 / 7)^{*}$ & $(7 / 7)^{*}$ & $(5 / 7)^{*}$ & $(3 / 3)^{*}$ & $(3 / 3)^{*}$ \\
\hline $\mathbf{S} \times \mathbf{C C}$ & 2 & ns§ & ns & ns & ns & ns \\
\hline $\mathbf{S} \times \mathbf{S R}$ & 4 & ns & $(1 / 7)^{*}$ & ns & ns & ns \\
\hline $\mathbf{C C} \times \mathbf{S R}$ & 2 & ns & ns & ns & ns & ns \\
\hline $\mathbf{S} \times \mathbf{C C} \times \mathbf{S R}$ & 4 & ns & ns & ns & ns & ns \\
\hline $\mathbf{Y} \times \mathbf{S}$ & 2 & $(2 / 7)^{*}$ & $(4 / 7)^{*}$ & $(4 / 7)^{*}$ & $(2 / 3)^{*}$ & $(1 / 3)^{*}$ \\
\hline $\mathbf{Y} \times \mathbf{C C}$ & 1 & ns & ns & ns & ns & ns \\
\hline $\mathbf{Y} \times \mathbf{S R}$ & 2 & $(1 / 7)^{*}$ & ns & ns & ns & ns \\
\hline $\mathbf{Y} \times \mathbf{S} \times \mathbf{C C}$ & 2 & ns & ns & ns & ns & ns \\
\hline $\mathbf{Y} \times \mathbf{S} \times \mathbf{S R}$ & 4 & ns & ns & ns & ns & ns \\
\hline $\mathbf{Y} \times \mathbf{C C} \times \mathbf{S R}$ & 2 & ns & ns & ns & ns & ns \\
\hline $\mathbf{Y} \times \mathbf{S} \times \mathbf{C C} \times \mathbf{S R}$ & 4 & ns & ns & ns & ns & ns \\
\hline Error & 68 & & & & & \\
\hline \multicolumn{7}{|l|}{ Response I } \\
\hline Linear & & $(5 / 7)^{*}$ & $(7 / 7)^{*}$ & $(5 / 7)^{*}$ & $(3 / 3)^{*}$ & $(3 / 3)^{*}$ \\
\hline Quadratic & & $(1 / 7)^{*}$ & ns & $(1 / 7)^{*}$ & ns & ns \\
\hline
\end{tabular}

* Significant at the 0.05 probability level.

$\dagger$ The number of fine fescue or buffalograss shoots in $4000 \mathrm{~mm}^{-2}$.

$\$$ Number in parentheses indicates number of evaluations when treatment differences were significant at $P \leq 0.05$ over total number of evaluations.

$\S \mathrm{ns}=$ nonsignificant at the 0.05 probability level.

II Linear and quadratic responses of seeding rate means.

percentage green cover and the poorest color and quality ratings when buffalograss was dormant (Fig. 1,2,3). These responses were not as evident in the spring overseeded CF treatment. This response may have been due to more rapid germination by SR $5100 \mathrm{CF}$ as reported by Lynch (1996), which may have allowed it to establish faster than BF and HF. Hard fescue has been reported to have a slow germination and establishment rate when compared to other fine fescues (Brar and Palazzo, 1995).

There were significant effects of overseeded fescues on turfgrass color retention from October to late May (Fig. 2). Lynch (1996) reported good winter color retention with BF. Although not a part of the study, the non-overseeded dormant buffalograss turfs growing in adjacent areas were observed to have a visual appearance similar to a color rating of 1.0 in October. At the same time, the BF treatment in this study had a turfgrass color rating of 6.7. While these observations are not intended to imply statistical significance, the observation certainly supports our contention of enhanced color retention achieved with the BF mixture. The fall and fallspring overseeding treatments maintained green cover for $>7 \mathrm{mo}$, while adjacent non-overseeded buffalograss was green for only $5 \mathrm{mo}$.

\section{Seeding Rate Study}

There were significant interactions for turfgrass color, green cover, and density between years and species or seeding rates on some evaluation dates (Table 3,4). However, trends were similar for both years and data were not reported separately. There were no significant interactions among treatments for turfgrass quality, color, green cover, and species shoot density, but species and seeding rate main effects were significant.

Table 4. Mean shoot density for fine fescue and buffalograss and percentage of fine fescues in mixtures as influenced by main effects of species, seeding rate, and core cultivation treatments.

\begin{tabular}{|c|c|c|c|c|c|c|c|}
\hline \multirow[b]{3}{*}{ Treatments } & \multicolumn{6}{|c|}{ Shoot density } & \multirow{3}{*}{$\begin{array}{c}\text { Fine fescue } \\
\text { composition } \\
\text { of mixture }\end{array}$} \\
\hline & \multicolumn{2}{|c|}{ May } & \multicolumn{2}{|c|}{ July } & \multicolumn{2}{|c|}{ September } & \\
\hline & Fine fescue & Buffalograss & Fine fescue & Buffalograss & Fine fescue & Buffalograss & \\
\hline & & & No. & $\mathbf{m}^{-2}$ & & & $\%$ \\
\hline \multicolumn{8}{|l|}{ Overseeded species } \\
\hline Blue fescue & 1.31 & 0.32 & 1.12 & 0.44 & 1.13 & 0.45 & $75 \dagger$ \\
\hline Hard fescue & 1.40 & 0.28 & 1.33 & 0.36 & 1.45 & 0.34 & 81 \\
\hline Chewings fescue & 1.16 & $\mathbf{0 . 3 3}$ & 1.14 & 0.43 & 1.29 & 0.34 & 77 \\
\hline LSD (0.05) & 0.06 & 0.03 & 0.06 & 0.03 & 0.07 & 0.44 & \\
\hline \multicolumn{8}{|l|}{ Seeding rate, $\mathrm{g} \mathrm{m}^{-2}$} \\
\hline 10 & 1.13 & 0.36 & 1.08 & 0.46 & 1.13 & 0.43 & $73 \div$ \\
\hline 20 & 1.32 & $\mathbf{0 . 3 0}$ & 1.23 & 0.41 & 1.32 & 0.37 & 78 \\
\hline 30 & 1.41 & 0.26 & 1.28 & 0.37 & 1.42 & 0.33 & 81 \\
\hline LSD (0.05) & 0.06 & 0.03 & 0.06 & 0.03 & 0.07 & 0.04 & \\
\hline \multicolumn{8}{|l|}{ Core cultivation } \\
\hline Double pass & 1.33 & 0.27 & 1.26 & 0.38 & 1.36 & 0.33 & $80 \S$ \\
\hline Single pass & 1.23 & 0.34 & 1.14 & 0.44 & 1.21 & 0.42 & 75 \\
\hline LSD (0.05) & 0.05 & 0.03 & 0.05 & 0.03 & 0.06 & 0.04 & \\
\hline
\end{tabular}

$\dagger$ Fine fescue composition of the mixture averaged over seeding rates and growing season.

$\$$ Fine fescue composition of the mixture averaged over species and growing season.

$\S$ Fine fescue composition of the mixture averaged over species, seeding rates, and growing season. 


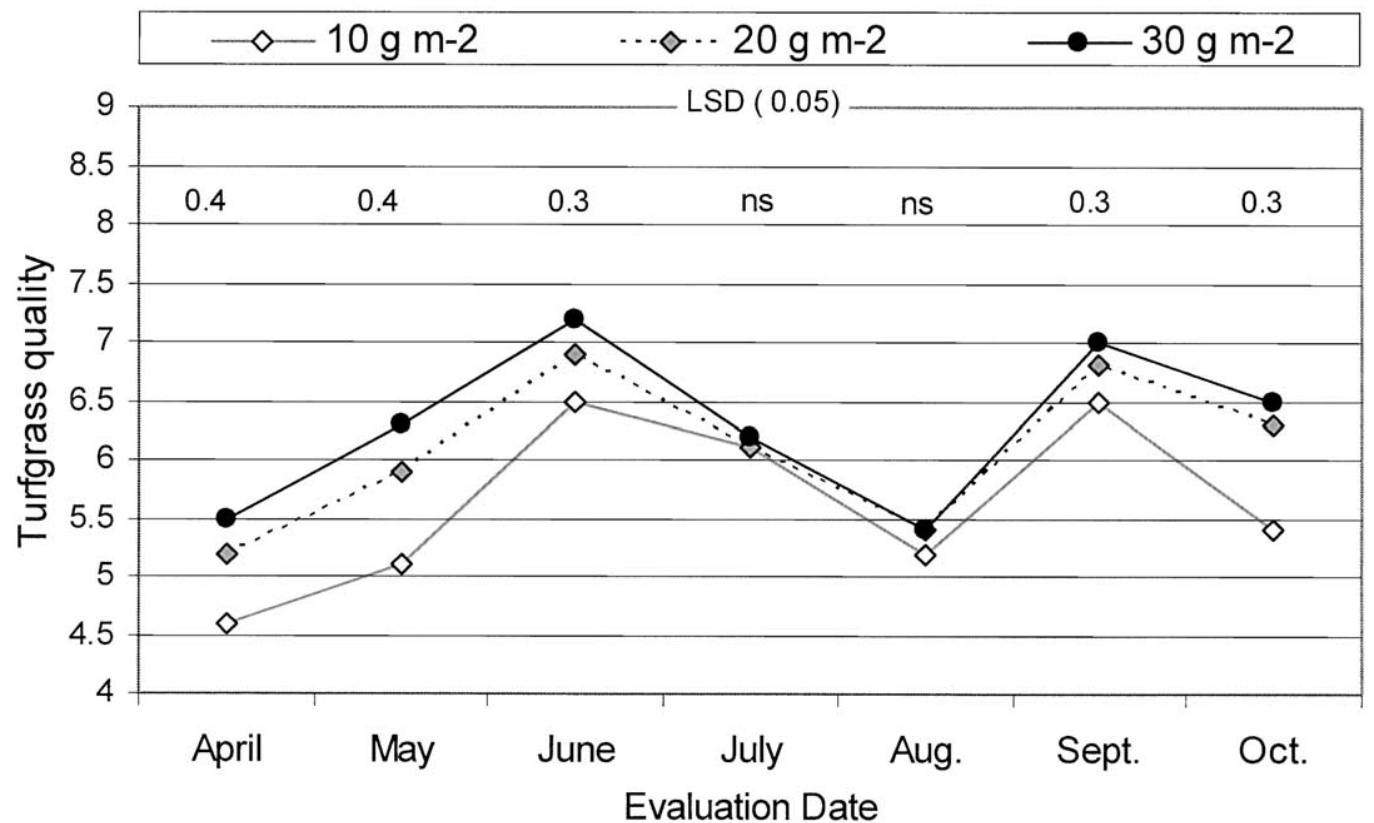

Fig. 4. Mean turfgrass quality for seeding rate treatments, averaged over 2002 and 2003 . Turfgrass quality was based on a 1-9 visual rating scale, with $1=$ poorest, $6=$ acceptable, $9=$ best. LSD values are for comparing between seeding rates.

There was a linear response for seeding rate, with each increment between 10 and $30 \mathrm{~g} \mathrm{~m}^{-2}$ resulting in an increased fine-leaved fescue shoot density (Table 4), and turfgrass quality (Fig. 4, 5), color (Fig. 6), and green cover (Fig. 7). However, mean separation indicated no differences between the 20 and $30 \mathrm{~g} \mathrm{~m}^{-2}$ seeding rate treatments for turfgrass quality, color, and green cover. Turfgrass quality, color, and green cover differences diminished for all seeding rates when buffalograss was actively growing in the summer. The higher seeding rates established better than the $10 \mathrm{~g} \mathrm{~m}^{-2}$ treatment. The $10 \mathrm{~g}$ $\mathrm{m}^{-2}$ seeding rate resulted in segregation and a patchlike turf appearance during the first year, but this non- uniform appearance diminished in the second year. In Utah, Johnson (2003) found 10 and $20 \mathrm{~g} \mathrm{~m}^{-2}$ fine-leaved fescue seeding rates in a buffalograss overseeding study resulted in similar species compositions. Watschke and Schmidt (1992) reported in a review article that establishment conditions influence seeding rate recommendations.

There were differences in shoot densities among fineleaved fescue species (Table 4). Fine-leaved fescue comprised 77,81 , and $75 \%$ of the tillers in $\mathrm{CF}, \mathrm{HF}$, and $\mathrm{BF}$ treatments when compared over all seeding rates and the growing season. As in the seeding date study, fineleaved fescue composition was highest in May for both

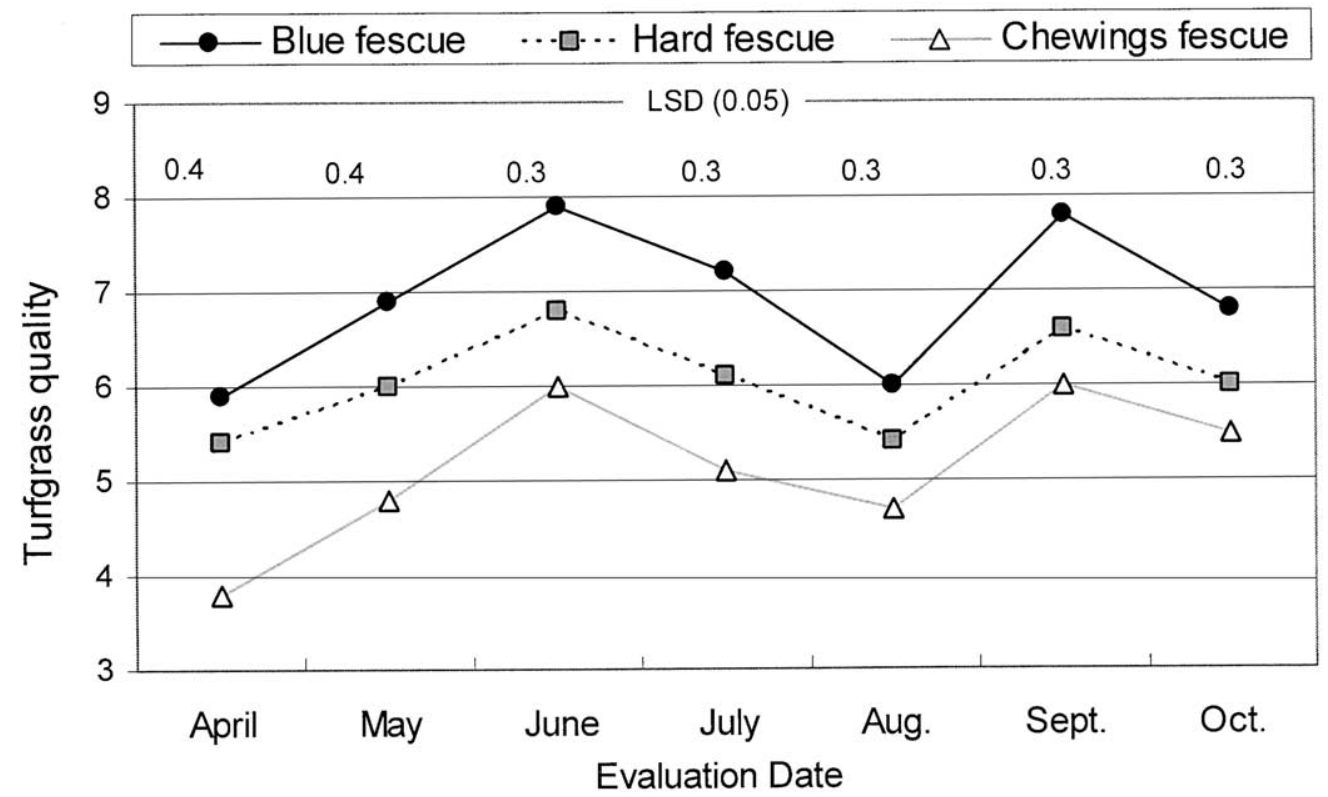

Fig. 5. Mean turfgrass quality for overseeded fine fescue species averaged over 2002 and 2003 . Turfgrass quality was based on a 1-9 visual rating scale, with 1 = poorest, 6 = acceptable, $9=$ best. LSD values are for comparing between species. 


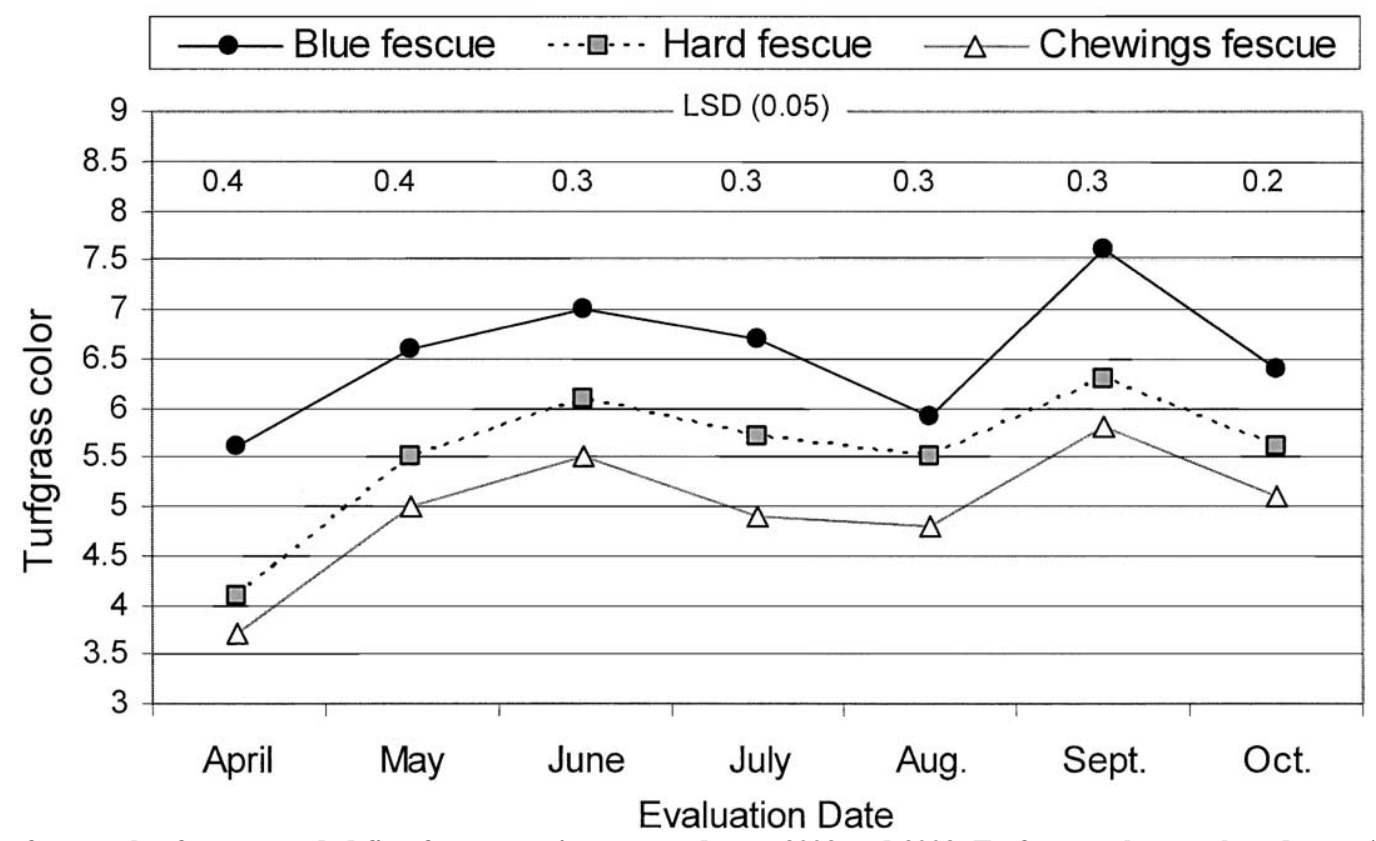

Fig. 6. Mean turfgrass color for overseeded fine fescue species averaged over 2002 and 2003 . Turfgrass color was based on a 1-9 visual rating scale, with 1 = straw brown, $6=$ light green, $9=$ dark green. LSD values are for comparing between species.

$\mathrm{BF}$ and $\mathrm{HF}$ treatments. The fine-leaved fescue composition decreased while buffalograss increased from late spring to midsummer.

As in the seeding date study, buffalograss overseeded in the fall trial with $\mathrm{BF}$ produced the best turfgrass quality and darkest green color (Fig. 5, 6). No differences in turfgrass green cover were observed between $\mathrm{BF}$ and HF treatments (Fig. 7). All fine-leaved fescue species improved green cover when buffalograss was dormant. Turfgrass green cover varied from around $70 \%$ in April, to $95 \%$ in July, and to $84 \%$ in mid-October. Similar to the seeding date study, green cover was evident for $>7$ mo with the fine-leaved fescue-buffalograss mixtures compared to 5 mo for buffalograss monostands.
Core cultivation treatment impacted species shoot density on three of three dates in the fall trial (Table 3). The double-pass CC treatment increased fine-leaved fescue in the turfgrass stand by $5 \%$ when compared to the single-pass CC treatment (Table 4). However, the double-pass $\mathrm{CC}$ treatment reduced buffalograss shoot density. The level of $\mathrm{CC}$ treatment had an impact on turfgrass color ratings in the fall-seeded trial on two of seven dates (Table 3). Double-pass CC treatments had better turfgrass color ratings when the buffalograss was dormant.

Although early attempts to mix warm- and cool-season turfgrasses have mostly failed (Davis, 1958; Beard, 1973), recent development of more aggressive cool-sea-

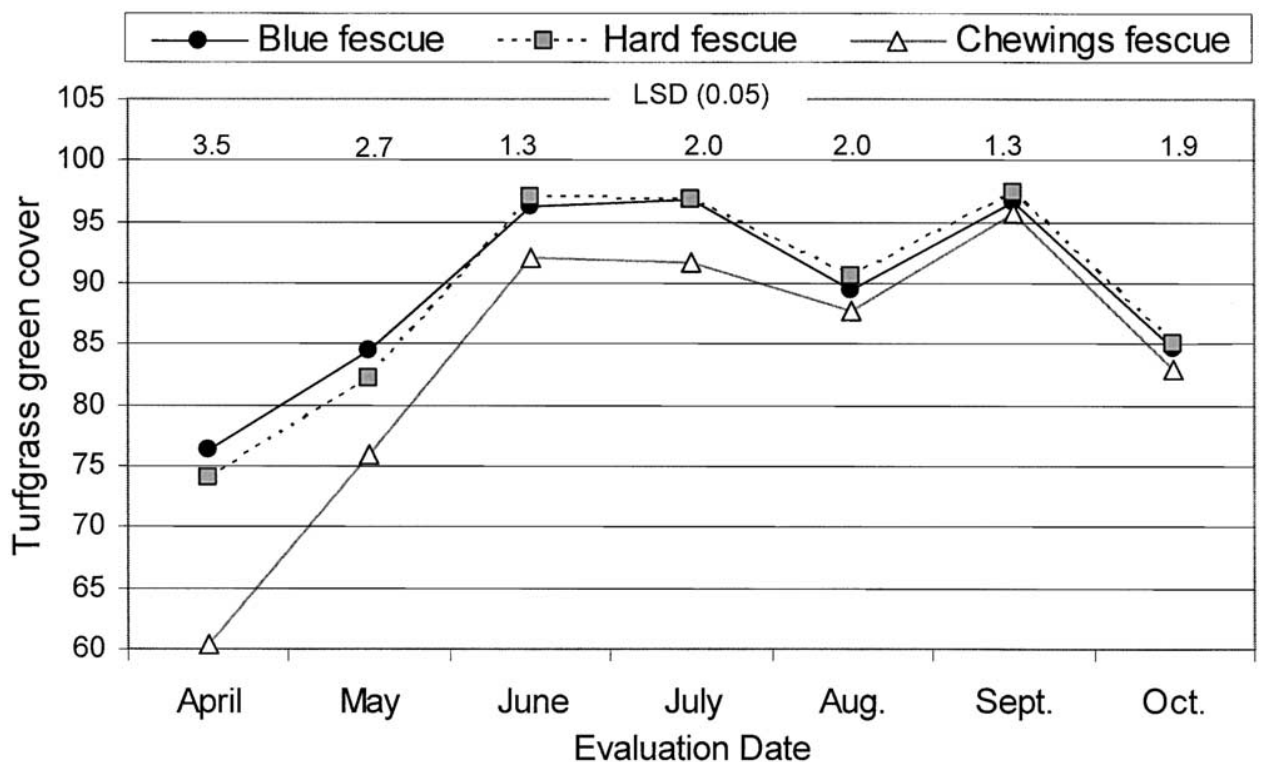

Fig. 7. Mean turfgrass green cover for overseeded fine fescue species, averaged over 2002 and 2003 . Turfgrass green cover was based on a visual estimate of $0-100 \%$ of existing turfgrass. LSD values are for comparing between species. 
son grasses (Turgeon, 1991) may decrease the warmseason species advantage during summer stress periods. In this study, botanical composition of the mixtures overseeded in fall reached 75 to $80 \%$ fine-leaved fescue and 20 to $25 \%$ buffalograss 2 yr after overseeding. Johnson (2003) reported similar results with fine-leaved fescues in a buffalograss mixture comprising $>80 \%$ of the species composition. The high percentage of fescues may cause some concern for long-term management of these mixtures.

In summary, the results from the seeding date and rate studies indicated that buffalograss turf overseeded with $\mathrm{BF}$ in the fall provided the best turfgrass quality, color, and green cover when buffalograss was dormant. Spring overseeding resulted in poor establishment. The fine fescue seeding rate effect was linear for shoot density, turfgrass quality, color, and green cover. Mean separation indicated no differences in turfgrass quality, color, and green cover between 20 and $30 \mathrm{~g} \mathrm{~m}^{-2}$. Thus, the $20 \mathrm{~g}$ $\mathrm{m}^{-2}$ seeding rate is recommended. The $\mathrm{BF}-$ buffalograss mixture overseeded in fall exhibited $80 \%$ green cover when buffalograss was dormant. This mixture extended the green cover for more than 2 mo. The results of these studies support the use of fine fescue and buffalograss mixtures as a means of enhancing turfgrass performance.

\section{REFERENCES}

Baker, B.S., and G.A. Jung. 1968. Effect of environmental conditions on the growth of four perennial grasses. I. Response to controlled temperature. Agron. J. 60:155-158.

Beard, J.B. 1973. Turfgrass: Science and culture. Prentice Hall. Englewood Cliffs, NJ.

Brar, G.S., and A.J. Palazzo. 1995. Shoot and root development of tall and hard fescues in two different soils. J. Environ. Qual. 24:777-780.

Davis, R.R. 1958. The effect of other species and moving height on persistence of lawn grasses. Agron. J. 50:671-673.

Dernoeden, P.H., M.A. Fidanza, and J.M. Krouse. 1998. Low maintenance performance of five Festuca species in monostands and mixtures. Crop Sci. 38:434-439.

Falkenberg-Borland, D.F., and J.D. Butler. 1982. Buffalograss a "new" turfgrass for golf courses. USGA Green Section Record 20(5): 6-8.
Foy, J.H. 1998. The pros and cons of fairway overseeding. Green Section Record 36(5):5.

Hanson, A.A., F.V. Juska, and G.W. Burton. 1969. Species and varieties. p. 370-409. In A.A. Hanson and F.V. Juska (ed.) Turfgrass science. Agron. Monogr. 14. ASA, Madison, WI.

Hartley, H.O. 1950. The maximum F-ratio as a shortcut test for heterogeneity of variance. Biometrika 37:308-312.

Johnson, P.G. 2003. Mixtures of buffalograss and fine fescue or streambank wheatgrass as a low-maintenance turf. HortScience 38:1214-1217.

Longer, D.E. 1998. Overseeding warm season lawns with cool season turfgrass species. p. 72-75. In J.R. Clark and M.D. Richardson (ed.) Horticultural Studies 1998 (Research Series 466). Ark. Agric. Exp. Stn., Univ. of Ark. Div. of Agric., Fayetteville, AR.

Lynch, S. (ed.) 1996. Seed specification manual. 1st ed. Seed Research of Oregon, Inc. Cascade Printing Co., Corvallis, OR.

Petersen, J.L., and L.E. Moser. 1985. Response of an irrigated cooland warm-season grass mixture to nitrogen and harvest scheme. J. Range Manage. 38:33-37.

Pitman, W.D. 1999. Response of 'Georgia 5' tall fescue-common bermudagrass mixture to season of nitrogen fertilization on the coastal plain. J. Plant Nutr. 22:1509-1517.

Pozarnsky, T. 1983. Buffalograss: Home on the range, but also a turfgrass. Rangelands. 5:214-216.

Roberts, E.C. 1990. Fine fescue: A kinder, gentler lawngrass. Seed World 128(9):16-19.

SAS Institute. 1999. SAS/STAT user's guide. Release 8.0. SAS Ins. Cary, NC.

Stoutemyer, V.T. 1953. Grass combination for turfs. Calif. Agric. 7(11):9-10.

Turgeon, A.J. 1991. Turfgrass management. Prentice Hall, Englewood Cliffs, NJ. Watschke, T.L. 1990. Low-maintenance grasses for highway roadsides. Grounds Maintenance 25(8):40-42.

Watschke, T.L., and R.E. Schmidt. 1992. Ecological aspects of turf communities. p. 129-174. In D.V. Waddington, R.N. Carrow, and R.C. Shearman (ed.) Turfgrass Science. Agron. Monogr. No 32. ASA, CSSA, and SSSA, Madison, WI.

Wehner, D.J., and T.L. Watschke. 1981. Heat tolerance of Kentucky bluegrass, perennial ryegrass, and annual bluegrass. Agron. J. 73: 79-84.

Wenger, L.E. 1940. Inflorescence variation in buffalograss, Buchloe dactyloides. J. Am. Soc. Agron. 32:274-277.

Wenger, L.E. 1943. Buffalo grass. Bull. 321. Kans. Agric. Exp. Stn., Manhattan, KS.

Wilkinson, S.R., L.F. Welch, G.A. Hillsman, and W.A. Jackson. 1968. Compatibility of tall fescue and coastal bermudagrass as affected by nitrogen fertilization and height of clip. Agron. J. 60:359-362.

Youngner, V.B. 1958. Tall fescue-Pensacola bahiagrass combination. Southern California Turfgrass Culture. 8:24. 